\title{
A crise redescobre o caminho da fonte
}

Pe. Alfredo José Gonçalves, cs ${ }^{1}$

A pandemia do novo coronavírus, ou Covi-19, traz uma experiência sem precedentes. É uma crise de ordem global, planetária. Cientistas e ambientalistas, com razão, falam de uma reação da natureza à devastação e contaminação do meio ambiente. Febre devida ao ritmo acelerado do sistema de produção e consumo em vigor. Toda crise é ambígua. Uma cirurgia que rasga o tumor não tanto para expô-lo, mas para curar. Situação-limite da vida que, apesar do sofrimento, costuma depurar, purificar, rever rota e rumo. Nela há sempre um lado trágico e outro desafiador: Reconduz ao berço e ao colo da mãe, mas também pode conduzir à fronteira. Num primeiro impacto, leva a um saudosismo melancólico. Em seguida, deixa aí os fracos com suas mágoas e, aos fortes, interpela a descortinar novos horizontes.

O desafio consiste em passar da crise à encruzilhada. Do deserto a um oásis. Crise significa dor, choro, lágrimas e até desespero. Tende ao isolamento, a fechar-se em si mesmo, recusando o confronto. O pranto cega e não permite enxergar o caminho nem as pessoas que estão ao lado. Já a encruzilhada, num estágio superior, pressupõe três aspectos interligados: levantar a cabeça e enxugar o pranto, deparar-se com uma bifurcação de veredas alternativas e fazer escolhas para retomar a travessia.

Os parágrafos que seguem reúnem alguns elementos de energia para a superação deste túnel escuro da pandemia. Não se trata de um estudo sobre mística, e sim de fragmentos de espiritualidade que podem nos ajudar

${ }^{1}$ Sacerdote religioso da Congregação dos Missionários de São Carlos (Scalabrinianos). Formado em filosofia e teologia. Foi diretor do CEM-Centro de Estudos Migratórios de São Paulo, Assessor do Setor Pastoral Social da CNBB, Superior Provincial na Província São Paulo e Vigário Geral da Congregação. 
a erguer os olhos, vencer a crise pela encruzilhada e fazer as devidas escolhas. Um convite a mergulhar a alma num oceano infinito de água viva que revigora e vivifica. Permitam-me falar de um poema em cinco binômios: ruído e silêncio, fonte e sede, expectativa e esperança, casa e mesa, espetáculo e horizonte.

\section{Ruído - silêncio}

O universo urbano, hoje majoritário, representa um palco rumoroso. Além dos ruídos externos, cada um teme defrontar-se com os próprios ruídos internos. Temos de ligar a TV, o rádio, o computador, o smartfone, conversar com alguém - tudo para escapar do encontro consigo mesmo. Não raro destilamos um veneno subreptício, pior ainda, contagioso. Para fugir a esse espelho perturbador, valem todos os meios. Abafamos os ruídos interiores com uma vida veloz e estridente. Nas metrópoles, multidão rima com solidão (Cfr A multidão solitária, de David Riesman). Neste momento solitário, um único minuto a sós consigo mesmo pode converter-se em uma tortura.

Mas a pandemia e a quarentena, combinadas, conduzem ao privilégio de cultivar a rara oportunidade de estar só. Nesse processo, se nos mantivermos abertos às novidades que a vida nos reserva, podemos descobrir o tesouro oculto do silêncio. Este último desenha duas vias opostas: ou é um deserto ressequido e estéril, ou um tempoespaço kairológico povoado de boas recordações. O silêncio estéril não passa de rumor que impede a escuta, o diálogo e o encontro. É marcado, com frequência, pelo martelar das palavras, no plural e com letra minúscula.

Já o silêncio povoado torna-se terreno fecundo. Um tesouro de pérolas colhidas nos caminhos labirínticos e tortuosos da vida. Constitui um solo onde nasce a verdadeira Palavra, no singular e com maiúscula. Não seria exagero afirmar que somente uma profunda atitude de silêncio, meditação e contemplação é capaz de gerar a 
Palavra nova. Aquela que cria, liberta, ilumina, fortalece, conforta e se abre à novidade do momento. O silêncio é a oficina ou o útero da Palavra criativa. Nele é que se gestam, nascem e crescem os interrogativos que questionam.

Quem é incapaz de silenciar, pouco ou nada de tem a dizer. Cai no palavreado oco e vazio. Vale a rima: quem não reflete se repete. Quantas vezes quem não sabe o que dizer põe-se a falar! Convém notar que a Boa Nova de Jesus sobre o Reino vem à luz depois de 30 anos de silêncio e escuta. A família de Nazaré é a escola do silêncio: José, que não tem voz, mas é o homem certo no lugar certo para proteger a família; de Maria, diz a narrativa que "guardava e meditava", como logo veremos; quanto a Jesus, o silêncio o leva ao deserto, onde a ausência de rumor e de vida, faz voltar-se sobre a própria vocação no projeto do Pai.

Este silêncio do isolamento social tem dupla face. De um lado, pode significar tempo de tédio para nós mesmos e para os que convivem conosco. Neste caso, o máximo que conseguiremos fazer é tolerar os ruídos uns aos outros. Por outro lado, existe a possibilidade de substituir esse aspecto negativo por uma proposta positiva. Aqui o desafio é redescobrir, resgatar e ressegnificar as dores e amores que marcaram a existência. Por duas vezes no mesmo capítulo, ao narrar a infância de Jesus, Lucas escreve que, enquanto o menino crescia em "estatura e sabedoria", "Maria guardava e meditava em seu coração” (Lc 1, 19.51).

Que significa guardar e meditar? Antes de tudo, analisar os acontecimentos com os olhos do coração e a partir da fé, descobrindo neles um novo sentido para a trajetória humana sobre a face da terra. Diz o ditado popular que "Deus escreve direito por linhas tortas". Nas adversidades do cotidiano, a mão invisível do Criador continua aperfeiçoando a sua Obra. Depois, a expressão remete a uma sabedoria oculta, a qual, no pergaminho vivo dos fatos, identifica as digitais de Deus nas coordenadas da história. Dissecar profeticamente a obra humana significa 
descobrir nela o DNA divino, que a reveste de amor e misericórdia. Juntamente com a Palavra, filha da escuta, nascem a acolhida, o diálogo, o encontro e a gratuidade. No fogo lento e sereno do silêncio forja-se a Palavra que será capaz de nos conduzir da escravidão à liberdade, das trevas à luz, do pecado à graça, da morte à vida. Quando as palavras vãs dão lugar à verdadeira Palavra, descortina-se um mundo onde tudo é recriado.

\section{Espetáculo - horizonte}

A obra "Sociedade do espetáculo" (cfr. Guy Debord), retrata, entre outras coisas, o mosaico plural e complexo do mercado e as mercadorias, onde impera dinheiro e comércio, riqueza e poder. O sistema de produção-consumo de um punhado de ricos contrasta com a pobreza e da fome de uma grande maioria. O contexto de um mercado globalizado - injusto e assimétrico, polifônico e polissêmico - enche os olhos e esvazia o bolso. O fogo de artifício no céu e os shoppings centers na terra, profusamente iluminados, fascinam e seduzem. Tudo isso reduz a fragmentos o tecido social e o ser humano, dispersando as energias. Míopes ou cegos, navegamos como barcos à deriva e sem bússola. Onde está o rumo e o farol do porto seguro?

Nesse cenário espetacularizado, facilmente nos desviamos do foco, da meta, do horizonte a ser alcançado. O confinamento compulsório força-nos a uma parada. De novo abre-se uma bifurcação de dupla face: ou continuamos nesse afã ansioso e doentio para satisfazer os desejos primários e imediatos, mesmo trancados em casa, ou decidimos aproveitar esse tempo-espaço para redirecionar o rumo e o fim da existência. Repete-se a lição já mencionada no item anterior. Quem é incapaz de parar, será também incapaz de dar passos criativos e inovadores no projeto de uma libertação integral. Somente quem sabe deter-se para avaliar, saberá caminhar em ritmo alternativo. Claro, é mais fácil seguir no piloto automático do mercado, continuar o 
traçado estabelecido, do que parar e recriar novas veredas. Mas, "o real não está no início nem no fim, ele se apresenta para nós é no meio da travessia" (cfr. ROSA, Guimarães, Grande sertão, veredas).

A segunda face da bifurcação reside no esforço para distinguir o que é essencial do que é supérfluo. Nossas casas, gavetas e armários em geral estão abarrotados de bijuterias e futilidades. A travessia se torna pesada, o que dificulta manter o objetivo fixado. Daí a pergunta: o que é indispensável e o que é secundário nos valores que guiam a existência? Um retiro para meditar e discernir, ainda que não programado, ajuda a corrigir o foco da trajetória, poupa dores e dissabores. Entra em cena a conversão: no trânsito, converter é virar à esquerda ou à direita. Momento favorável para fazer ajustes, canalizar desejos e energias, rever valores e contravalores.

Quanto mais o caminheiro se aproxima do horizonte, mais este último parece lhe fugir. Não há horizonte fixo e definitivamente acabado. Ele se desloca e se distancia ao ritmo de nossos passos. Os olhos podem vislumbrá-lo, mas as mãos e os pés jamais o alcançam. Cada contexto histórico no conjunto de suas próprias circunstâncias, exige um desenho novo para o projeto. Este se faz, se desfaz e se refaz de acordo com as vicissitudes e adversidades das aventuras humanas. Mas não é só isso!

O horizonte da vida humana não se reduz a uma determinada estrutura econômica, social, político ou cultural. Cada construção específica, embora radicada no chão da travessia humana, somente terá sua plenitude e sua perfeição na esfera do Reino. Este mantém-se como uma instância crítica, não acima nem além dos embates históricos, mas no interior mesmo desses embates. Aí interpela movimentos sociais, igrejas, associações, organizações e instâncias políticas: é preciso a cada passo rever princípios e decisões, em vista do bem comum. Cabe a pergunta: que tipo de horizonte devemos desenhar após a 
Covid-19? De cara, uma existência mais sóbria e frugal, o que está em sintonia com o uso responsável dos bem naturais. O conceito de "pobreza evangélica", antes reservado à vida religiosa, hoje se estende a toda a sociedade. Voltamos a São Francisco de Assis!

\section{Expectativa - esperança}

Expectativa é palavra chave em meio à profusão de novidades com que o mercado total nos bombardeia diariamente. O marketing, a propaganda e a publicidade, cada vez mais apelativos e estridentes, aguçam a sede natural de "coisas novas", criado uma "agitação febril" (cfr. Papa Leão XIII, Rerum Novarum, 1891), no contexto do mundo contemporâneo. A Revolução Industrial sela o "século do movimento". As máquinas a vapor encurtam tempo e espaço. Milhões de emigrantes escapam do velho continente, deslocam-se em todas as direções atrás das migalhas do capitalismo incipiente. Ontem como hoje, a ilusão da ciência, da tecnologia e do progresso nos apertam nos tentáculos das expectativas. Estas, porém, costumam responder aos instintos, paixões, desejos e interesses imediatos, sejam eles de ordem pessoal e familiar, comunitária e corporativa, religiosa, política ou ideológica.

Chega-se ao círculo vicioso e espiral que nos faz prisioneiros da busca insaciável. $\mathrm{Na}$ medida em que as expectativas ampliam o leque dos desejos, e na medida em que estes, por sua vez, giram na órbita daquelas, torna-se quase impossível escapar à armadilha do mercado. O mercado tenta responder à ansiedade. Desejos ilimitados geram ilimitadas expectativas. A quarentena desperta a necessidade de distinguir expectativa de esperança. Uma se norteia pelos desejos, a outra dá primazia às necessidades. A astúcia do mercado cria confusão entre ambas, igualandoas. A diferença é que os desejos são imperativos e sem fronteiras. Exigem imediata e total satisfação, como revela o comportamento das crianças. Já as necessidades tropeçam nas leis histórico-sociais e nos limites da natureza. 
Se os desejos primam pelo egocentrismo imanente, as necessidades se fundam nas relações entre a natureza e as pessoas, e entre estas e o Transcendente. Diante dessa relação, uns e outras devem ser repensados. O desejo funciona como imã para as coisas materiais, no aqui e agora; a necessidade ultrapassa o mundo material, atendose à fé na busca de alternativas. A expectativa agarra-se com unhas e dentes ao prazer do presente, usufruindo de tudo e de todos para o "bem viver". A esperança, ao contrário, fixa as raízes na terra úmida e escura, sem dúvida, mas possui asas para voar ao encontro da utopia do "viver bem", na órbita do Reino.

A expectativa prende-se aos instintos primários e infla o ego, a esperança cimenta a solidariedade, reforçando o projeto comum. Abrindo-se ao diferente e estrangeiro, pavimenta a via que conduz ao Transcendente. Esperar é intuir que o caminho para mim mesmo passa necessariamente pelo outro e pelo Totalmente outro (cfr. LEVINÁS, E. Totalidade e Infinito, 1988). A expectativa quer ver, tocar, desfrutar; a esperança é um salto no escuro, confiante numa virada epocal. A primeira, fecha a história, a segunda se mantém aberta à irrupção de Deus na ação humana.

\section{Casa e mesa}

Do ponto de vista simbólico, casa e mesa remetem ao carinho, ao refúgio, ao calor e à intimidade familiar. Mas abrigam também tensões, discórdia e conflitos. Não raro a violência sofrida na sociedade abate-se sobre as pessoas com as quais convivemos no cotidiano. Às vezes até com as pessoas que mais amamos, ou deveríamos amar. São frequentes as agressões a mulheres e crianças no interior da própria família. Os números de feminicídios não param de aumentar. Pior, têm crescido no decorrer mesmo deste trágico flagelo. Mas casa e mesa mantêm sua rica simbologia. 
Comecemos com a casa. Em termos figurados, ela é a roupa de um grupo que se quer bem, família ou comunidade. Todo grupo que se ama, cria uma intimidade repleta de palavras, toques e gestos singulares. Laços absolutamente privados, que aquecem e enriquecem. Para garantir essa privacidade única, os membros do grupo necessitam de paredes e do teto que os protege de olhares alheios e indiscretos. Lar é coditio sine qua non na preservação da dignidade humana. Família sem casa equivale a um corpo sem roupa. A nudez se expõe à curiosidade corrosiva dos transeuntes, conhecidos ou não. Em tais condições, impossível manter o mínimo de dignidade!

Durante a quarentena, a obrigatoriedade do confinamento pode reconverter a casa numa espécie de laboratório para relações mais criativas. Estas tendem ao cultivo de novas formas de lidar com os sentimentos, experiências e emoções, de um lado, e, de outro, com as fraquezas, fragilidades e limitações de cada indivíduo. Juntos somos capazes de cuidar, cultivar e administrar, com o devido respeito, a alteridade de cada pessoa, como filho e filha de Deus. Nesse empenho, todos e cada um sairemos do túnel melhores e mais ricos. O olhar e a proximidade com os irmãos abrem uma perspectiva mais ampla para a relação profunda com o Pai.

Quanto à mesa, poucos símbolos são tão característicos do ser humano. O cão come sozinho e tende a arreganhar os dentes para outro que se aproxime. Os homens e as mulheres, ao contrário, comem à mesa. É verdade que hoje em dia, em muitas casas, a televisão, o celular e o computador baniram a refeição familiar. Mas onde ela ainda se mantém, a presença do outro é o verdadeiro tempero do alimento. Isso quer dizer que quanto mais profunda a relação com a pessoa que está sentada à frente, tanto mais saborosa será comida. Não seria exagero afirmar que, à mesa, a gente come e se come. Enquanto o 
alimento nutre o corpo, o olhar, o sorriso, a conversa e a história dos comensais nutrem o coração, a mente e a alma.

O conceito de comensalidade torna-se outro laboratório de viva espiritualidade. Existe coisa mais triste que comer sozinho ou comer depois de uma briga!? $\mathrm{O}$ ato de comer em comum explica a festa e os respectivos convidados. Fome de pão não é o motivo principal que nos leva a celebrar, mas a necessidade de encontro, diálogo, companhia. Somos seres relacionais e as relações são acompanhados de comida e bebida. Na mesa, uma vez mais, crescem contemporaneamente os laços da amizade e as energias espirituais que aproximam e fortalecem.

Cabe um olhar à prática evangélica de Jesus. Em sua travessia pela Galileia, a Samaria e a Judeia, com frequência inusitada vemos o Mestre sentado à mesa. Convida e faz-se convidar pelas pessoas e famílias, contribuindo para a alegria da festa ou do banquete, como no casamento de Caná (Jo 2,1-12). Não à toa, é acusado de "comilão e beberrão" (Mt 11,19). No episódio de Emaús (Ic 24,13-35), os discípulos o reconhecem "ao partir o pão", o que significa que esse era um gesto comum no seu convívio como os que o seguiam.

Central, porém, será a última ceia e tudo que a acompanha. Vale a pena conferir os capítulos 13 a 17 do Quarto Evangelho. João, o discípulo amado, nos lega em seu relato uma tríplice herança: a) um evangelho dentro do Evangelho, onde b) nos deparamos com o coração materno de Jesus, o qual, c) antes de partir para o Pai, deixa uma espécie de testamento espiritual. "Ardentemente quis comer esta ceia convosco", diz outro evangelista (LC 22,15). Na véspera da paixão e morte, Jesus quis nutrir-se e nutrir seus amigos mais íntimos, deixando a si mesmo como alimento vivo e verdadeiro para as experiências mais dolorosas - o pão da vida eterna.

Sede - fonte 
Crise resseca o espírito. A sofreguidão que nos leva ao pote sinaliza uma sede mais profunda, como a nascente do rio nos alerta para outro tipo de água viva. O fato é que, no poço existencial da história, particular ou coletiva, água e sede se encontram e se fundem. A pessoa humana e o patrimônio cultural formam um poço de profundidade jamais alcançada. Trata-se sempre de dois tipos de sede e dois tipos de água. Uma e outra, consciente ou inconsciente, chamam a atenção para a busca existencial, vital, visceral. A sede provocada pela pandemia deixa igualmente ressequidas as culturas distintas, múltiplas e plurais. Há muito nos assola a sede: de orientações morais, de referências substanciais, de princípios duradouros, de relações íntimas e gratuitas, de um novo convívio com o meio ambiente - enfim, de um ponto sólido na "modernidade líquida" (cfr. BAUMAN, Zygmunt, obra homônima).

É forte a tendência ao naufrágio público, que leva a afogar-se nas águas turvas e torvas dessa modernidade líquida. Impõe-se a necessidade de retornar à fonte, onde a água é mais límpida, cristalina e transparente. Retornar ao poço de nossa memória e da travessia da humanidade como história da salvação. Nela, descobrimos que, em se tratando de pessoa ou sociedade, ninguém é só sede e ninguém é só água; ninguém é sede o tempo todo e ninguém é água o tempo todo. Todos, pessoas, povos e culturas, formamos uma mescla de água e sede.

No poço, lugar de cruzamentos, sede e água se encontram e se interpelam. Remetem-nos ao equilíbrio orgânico da harmonia e da paz. Convém não esquecer a insistência do Papa Francisco: como passar da globalização da indiferença à cultura da acolhida, do diálogo, do encontro e da solidariedade? O poço, além disso, é sempre ponto de chegada e ponto de partida. Nele chegam os pés sedentos e cansados, dele partem os corações revigorados. O poço lembra que a evangelização tem mão dupla: quem se diz evangelizador, termina sendo evangelizado; e inversamente, 
quem achamos que é necessário evangelizar, acaba se tornado evangelizador.

O poço chama e envia, congrega e dispersa, convida ao repouso e move para o caminho. Não se trata de estacionamento, e sim posto de gasolina. Nele nos detemos para refazer as energias e voltar à a estrada. A ideia de poço remete à perspectiva do horizonte, analisada no item dois. Sentamos por um momento na beira do poço, para logo levantar com o olhar atento ao rumo a ser tomado. Mas essa parada junto ao poço tende a enriquecer mutuamente os diferentes viajantes, que outra vez e sempre deverão dispersar-se. Com efeito, experimentando a mesma sede e bebendo da mesma água, eles podem nutrir-se e crescer com o que Gadamer chama de "fusão de horizontes" (Cfr. GADAMER, H.G. Verdade e método).

\section{Conclusão}

No deserto árido da quarentena, que sementes cultivamos em vista de um horizonte recriado? Lição da semente: antes de se levantar, ela mergulha as raízes no coração secreto da terra. De suas entranhas, extrai os nutrientes para a sobrevivência. Se a estiagem se prolonga, a planta se nutre daquilo que reteve no processo de formação. Guarda um tesouro oculto ao qual recorrer no tempo das "vacas magras". Mantém vivo o caminho de uma fonte que lhe irriga o organismo.

Antes de crescer para cima, a planta cresce para baixo, buscando alimento. Antes de dirigir-se ao ar livre, firma no chão suas sólidas bases, para não se tornar "caniço agitado pelo vento". Antes de embriagar-se com o azul do céu, bebe a lama em meio aos vermes. Antes de gerar folhas, flores e frutos, cria com os pés uma rede de auxílio contra as intempéries. Quanto mais estende e afunda as próprias raízes, mais poderá erguer-se do solo, forte e sobranceira. 
Crise humanitária, quarentena, deserto e silêncio eis um sulco na história para lançar novas sementes. Tempo de semear, de cultivar a planta, de cuidar do jardim. Cuidado é a palavra-chave desta experiência. Cuidar do outro, da família, dos pobres e excluídos, com relações humanas mais criativas, incluindo a "nossa casa comum", na expressão do Papa Francisco (cfr. Carta Encíclica Laudato si', 2015).

Momento de superar a crise, avançando para a encruzilhada. Várias veredas se abrem, alternativas se multiplicam e as escolhas exigem novos critérios, seja nos relacionamentos sociais, seja no uso correto dos recursos que a natureza nos oferece, seja no sentido de deixar para as gerações futuras um mundo mais rico e equânime, justo e sustentável, fraterno e solidário. "Quem semeia vento, colhe tempestade", diz a sabedoria popular. Mas o inverso também é verdadeiro: quem semeia olhares, sorrisos e gestos de amor, cria a possibilidade de um horizonte marcado por uma aurora de "novos céus e nova terra" 